\title{
History and the Debate Over Intellectual Property
}

\author{
Mike W. Peng, ${ }^{1}$ David Ahlstrom, ${ }^{2}$ Shawn M. Carraher, ${ }^{1}$ \\ and Weilei (Stone) $\mathbf{S h i}^{3}$ \\ ${ }^{1}$ University of Texas at Dallas, USA, ${ }^{2}$ The Chinese University of Hong Kong, Hong Kong, and \\ ${ }^{3}$ City University of New York, USA
}

ABSTRACT This article responds to recent calls for organizational research to address larger, more globally relevant questions and to pay attention to history, by analyzing the crucial debate over intellectual property rights (IPR) between the United States and China. Despite the recent US position, the United States has not always been a leading IPR advocate. Rather, it was a leading IPR violator during the nineteenth century. An institution-based view of IPR history suggests that both the US refusal to protect foreign IPR in the nineteenth century and the current Chinese lack of enthusiasm to meet US IPR demands represent rational choices. However, as cost-benefit considerations change institutional transitions are possible. We predict that to the same extent the United States voluntarily agreed to strengthen IPR protection when its economy became sufficiently innovation-driven, China will similarly improve its IPR protection.

KEYworDs China, history, institution-based view, intellectual property rights (IPR), United States

\section{INTRODUGTION}

A leading debate in contemporary US-China relations centers on intellectual property rights (IPR). Given the scope and scale of potential IPR violations in China, ${ }^{[1]}$ the United States has frequently sought improved IPR protection in China and has been frustrated by the lack of progress, in spite of recent improvements. What does the future of IPR protection in China hold? Despite the obvious importance of the IPR debate, it has attracted little attention from organizational scholars - and little coverage in the pages of Management and Organization Review (MOR). Do organizational scholars such as those in the MOR/International Association for Chinese Management Research (IACMR) community have anything to contribute to the debate over IPR?

Responding to recent calls for organizational research to address larger, more globally relevant questions (Davis, 2015; Lewin, 2015) and to pay attention to history (Ahlstrom, Lamond, \& Ding, 2009; Barley, 2016), we argue that a key to predicting the future development of IPR lies in a deeper understanding of 
history, which can help to clear up misconceptions. For example, many take for granted that the United States is a leading IPR champion and China a leading IPR violator. Yet ironically, as recently as in the nineteenth century, the United States was a leading IPR violator (Raustiala \& Sprigman, 2012, 2013). Between the founding of the United States in 1776 and the enactment of the Chace Act in 1891, pirating British publications (such as books) and entertainment (such as stage plays) was widely practiced by numerous Americans to make a living (and a 'killing') (Lohr, 2002). This article endeavors to demonstrate how history can help to identify patterns and further resonates with the recent call for international comparisons to better understand how history matters (Friedman \& Jones, 2011).

Leveraging an institution-based view of IPR protection (Peng, 2013; Peng, Ahlstrom, Carraher, \& Shi, 2017), we focus on why US institutions supported IPR violation initially. Next, we investigate why US institutions later changed to ban such piracy. How the United States went from being a leading IPR violator to a leading IPR champion is a fascinating chapter in history that, we argue, can help inform the modern debate over IPR. In doing so, we respond to recent calls for organizational researchers to address larger, more globally relevant questions with societal ramifications (Davis, 2015: 186; Lewin, 2015: 2) via 'significant historical research' as a way forward (Ahlstrom \& Wang, 2009; Barley, 2016: 6).

\section{THE INSTITUTION-BASED VIEW}

The institution-based view is part of a broader intellectual movement centered on the new institutionalism throughout the social sciences. Organizational scholars have increasingly realized that institutions are more than background conditions (Meyer \& Peng, 2016; Peng, 2003). Instead, 'institutions directly determine what arrows a firm has in its quiver as it struggles to formulate and implement strategy' (Ingram \& Silverman, 2002: 20). Consequently, an institution-based view has emerged (Ahuja \& Yayavaram, 2011; Marquis \& Raynard, 2015; Peng, Wang, \& Jiang, 2008). Further development can benefit from following well-accepted research designs of history research - 'probing over long periods of time and finding commonalities among institutions' (Wren, 1987: 341).

The institution-based view in the organizational literature (Ahuja \& Yaravaram, 2011; Marquis \& Raynard, 2015; Peng, Sun, Pinkham, \& Chen, 2009) has roots in sociological institutionalism (DiMaggio \& Powell, 1983; Scott, 2014) and economic institutionalism (North, 1990; Williamson, 1985) as well as allied fields such as political science (Hall \& Taylor, 1996; Pierson, 2004). Authors in the organizational field often take an integrative approach, drawing from various disciplines (Ahuja \& Yayavaram, 2011: 1633; Peng, 2003: 276; Peng et al., 2009: 64), which is the approach followed here.

The 'rules of the game' (North, 1990), an institution's most fundamental role is to reduce uncertainty and provide meaning (Scott, 2014). The institution-based view 'focuses on the dynamic interaction between institutions and organizations 
and considers strategic choices as the outcome of such an interaction' (Peng et al., 2009: 66). In other words, institutions are 'both constraints and facilitators' on the decisions and behavior of organizations (Ahuja \& Yayavaram, 2011: 1633).

A leading proposition of the institution-based view is that individuals (such as managers, policymakers, and consumers) and organizations (such as government departments and firms) 'rationally pursue their interests and make strategic choices within the formal and informal constraints in a given institutional framework' (Peng et al., 2009: 67). Of course, the rationality discussed here is bounded rationality (Williamson, 1985). Individuals and organizations are assumed to be 'intendedly rational, but only limitedly so' (Simon, 1961: xxiv). Often associated with institutional economics, this rational choice school is one of the three major schools of thought within the institutionalism literature - the other two are sociological and historical (Hall \& Taylor, 1996; Pierson, 2004).

Sociological institutionalism focuses more on the mimetic pressures from isomorphism and the meaning provided by institutions (DiMaggio \& Powell, 1983; Scott, 2014). Historical institutionalism argues that historical contexts shape institutions, which create path dependencies that are difficult to break (Arthur, 1994; David, 1985; Steinmo, Thelen, \& Longstreth, 1992). While there is theoretical tension among these three schools of thought, they may 'be more complementary and less competitive than we realize' (Pierson, 2004: 131; see also Peng et al., 2009: 64; Ahuja \& Yayavaram, 2011: 1633). In an effort to propel organizational research further, the institution-based view aspires to draw from the best insights from these three forms of institutionalism - rational choice, sociological, and historical (Hall \& Taylor, 1996). Before examining the institutions underpinning IPR protection, it may be useful to first discuss two 'popular' explanations concerning IPR in China: culture and politics.

\section{THE GULTURE AND POLITICS BEHIND IPR IN GHINA}

Today, China's IPR laws are generally well-crafted and have pushed a lot of IPR violation under ground (Chow, 2003; IP Commission, 2013; Yu, 2014b). However, enforcement continues to be weak. Despite some progress, repeated negotiations between the United States and China have not produced satisfactory headway. In the context of the contemporary US-China IPR debate, a fundamental puzzle is why China does not pay sufficient attention to IPR protection and why so many Chinese firms and individuals are willingly engaged in piracy, counterfeiting, and other acts of IPR violation (Yu, 2008). Various debate points can boil down to two popular explanations: culture and politics.

The cultural argument fingers Chinese culture, dating back 2500 years to Confucianism, for a major weakness: a lack of respect for IPR. For example, the title of Alford's (1995) influential book - To Steal a Book is an Elegant Offense: Intellectual Property Law in Chinese Civilization - sums it well. Suttmeier and Yao (2011: 19) further add that 'Chinese culture still seems to have trouble 
valuing intangible assets.' As culture generally changes slowly (Hofstede, 2007), though there is some debate about this (McCloskey, 2016), if it were the main driver of behavior concerning IPR, then it would be difficult to envision better IPR protection in China in the absence of significant changes to its culture.

However, is China the only country that has shown disrespect for IPR? The answer is no (Robinson, 2016). Enough examples exist to refute the notion that IPR violation is driven by certain deeply held, largely invariant cultural values (Peng, 2013). In China's pre-Qin period (before 221 BCE), traditional Chinese scholars despised the act of plagiarism (Feng, 2007). Numerous swings in IPR protection also occurred in Europe since the Roman Empire where plagiarism (such as appropriating poems and plays) was common (Bugbee, 1967; Jaffe \& Lerner, 2007). Significant violation and theft of IP were regularly noted in the Middle Ages as well (Jaffe \& Lerner, 2007). ${ }^{[2]}$ For example, in the fifteenth century, the Dutch busied themselves making counterfeit Chinese porcelain (Johns, 2009).

In the twentieth century, 1960s Japan was a global leader for counterfeit goods. In the 1970s and 1980s, Taiwan, South Korea, and Hong Kong grabbed this dubious distinction (Kumar, 2003; Peng, 2013), and recent music piracy has involved people from practically every country (Hill, 2007). For example, Russia is now home to some of the most notorious piracy websites in the world (Galtsova, 2008: 21). Clearly, IPR violation is not unique to China. The more abstract argument about a Confucian value system driving IPR violation does not stand up well to scrutiny.

A political school of thought in this debate suggests that 'Chinese political culture does not lend itself to the concept of IP ownership' (Zimmerman, 2013: 142). During the Mao era in China, the emphasis on public (state) ownership was directly at odds with the emphasis on private rights inherent in IPR (Lubman, 1999). During the subsequent reform period, China's decentralized political structure encouraged local protectionism. This made IPR protection more problematic (Chow, 2003; Mertha, 2007; Poncet, 2005). Although the IPR laws on the books now look impressive and are (mostly) compatible with WTO (2009) mandates, it is the weak enforcement that is often fingered as contributing to the unsatisfactory IPR protection.

However, in 2008 during the Beijing Olympics, the sale of fake Olympic merchandise completely disappeared (Yu, 2014a). Similar successes were achieved during the Asian Games in Guangzhou in 2010 and the Summer Youth Olympics in Nanjing in 2014. Did the counterfeiters become more patriotic? Or did the government demonstrate that effective protection of IPR was possible, once it was given political priority? Regardless of the answer, clearly the Chinese can be politically motivated and organizationally capable of eradicating IPR violation if so inclined. Thus, the political argument - just like the cultural argument - can also be rejected. Instead, when there is a will, there is a way. 


\section{THE INSTITUTIONS BEHIND IPR IN GHINA}

As 'rules of the game,' IPR institutions provide the incentive structures that affect the costs of doing business - in this case the costs of engaging via-a-vis the costs of not engaging in piracy and counterfeiting (Peng, 2013; Peng et al., 2017; Yu, 2014a). Given weak IPR protection (and weak enforcement if caught), thousands of firms and tens of thousands of individuals have made rational decisions (from their standpoint at least) to engage in piracy and counterfeiting (Hill, 2007; Li, 2004). Stronger IP protection such as criminalizing all counterfeiting activities instead of only criminalizing large scale counterfeiting above a certain threshold is likely to significantly reduce counterfeiters' incentives. Between 2007 and 2009, the WTO adjudicated the dispute between the United States and China (Yu, 2008, 2011). The United States advocated a 'zero tolerance' approach. China insisted on a 'threshold' approach, which would only penalize violations above the threshold of 'large scale' (or using the WTO vocabulary, 'commercial scale'). While the WTO (2009) respected China's threshold approach and the United States did not win, China's reluctance to criminalize all IPR violations was evident. A lingering question is: Why?

The institution-based view first highlights the path dependent nature of IPR development (North, 1990). Path dependence maintains that the choices one faces for any given circumstance are limited by related decisions made in the past, even though past circumstances may no longer be relevant (David, 1985). Earlier practices and initial conditions of potentially not paying enough attention to IPR thus cast a long shadow.

Second, when viewed from a relatively long span of three decades, China's IPR system 'has indeed come a very long way' (Yu, 2013: 88). It essentially started from scratch in 1985 (Lubman, 1999). Handling over one million patent applications annually since 2010 (Suttmeier \& Yao, 2011), China already has the world's largest volume of domestic patent applications (The Economist, 2014: 73) and it is now one of the world's leaders in filing international (ICT) patent applications (Yu, 2013: 88). While China's IPR regulations are fundamentally compatible with the letter of the expectations of the WTO and its sister organization, World Intellectual Property Organization (WIPO), critics note that their enforcement, however, does not appear to meet the spirit of such expectations.

Finally, institutional transitions moving toward a more effective IPR protection and enforcement regime have both costs and benefits (Mazzoleni \& Nelson, 1998; Moser, 2013; Peng, 2003, 2013). Given widespread scholarly diffusion, explicit international pressures, and initial legal reforms, it is unlikely that Chinese policymakers, managers, and scholars are not aware of the innovation-boosting benefits of better IPR protection (Abrami, Kirby, \& McFarlan, 2014; Lewin, Kenney, \& Murmann, 2016; McKinsey, 2015; Yu, 2008). However, even for proven violations, current law generally imposes a maximum fine of one million RMB $(\$ 160,000)$ - only in a small number of cases when the loss to the plaintiff and 
income of the defendant are difficult to assess can the judge award damages greater than one million RMB. However, the average award is only 190,000 RMB $(\$ 30,000)$, which is hardly enough to deter violations and that may not even cover legal costs (McKinsey, 2015: 115). Why does China not significantly increase the maximum fine for IPR violations? The reluctance seems to stem from the concern that at this early stage of China's development, satisfying US IPR demands may result in foreign (and primarily US) IP rights holders benefiting more (Liang \& Xue, 2010: 490; Yu, 2013: 97). In short, costs may exceed benefits.

How does the future of IPR protection look in China? We argue that the history of IPR development in the United States identifies interesting historical parallels and offers a great deal of insights to help inform today's debate.

\section{THE UNITED STATES AS AN IPR VIOLATOR ${ }^{[3]}$}

Although widely known to scholars (Chaudhry \& Zimmerman, 2009: 175; Khan, 2013: 67; Lopes \& Casson, 2012: 308; Raustiala \& Sprigman, 2013: 29), the US experience as a leading IPR violator during the nineteenth century is seldom mentioned as a part of the modern IPR discourse. It is important to note that we are not offering a radical revision or reinterpretation of the US IPR history in the nineteenth century. Our characterization of the United States as an IPR violator follows the mainstream views of historians who specialize in this era (Gordon, 2005; Khan, 2005).

Similar to our earlier rejection of the cultural and political arguments in the contemporary IPR debate (such as the Chinese culture was not aware of the importance of IPR and the Chinese polity was not capable of offering IPR protection), we can also reject the cultural and political arguments concerning nineteenth-century America. From its founding, the United States had a conceptualization of IPR and a formal system of IPR protection. George Washington, in his first inaugural speech, encouraged a system of protection for inventors. Abraham Lincoln, the only US president to hold a patent, was a strong proponent of IPR. Adopted in 1787, the Constitution of the United States included a provision for protecting IPR in Article I, Section 8:

The Congress shall have Power... To promote the Progress of Science and useful Arts, by securing for limited Times to Authors and Inventors the exclusive Right to their respective Writings and Discoveries.

However, such IPR protection only protected US authors and inventors. Section 5 of the 1790 Copyright Act explicitly stated (Yu, 2014b: 9):

Nothing in this Act shall be construed to extend to prohibit the importation or vending, reprinting or publishing within the United States, of any map, chart, book or books, written, printed, or published by any person not a citizen of the United States, in foreign parts or place without the jurisdiction of the United States. 
In short, foreign intellectual property was up for grabs. ${ }^{[4]}$ During much of the nineteenth century, American pirates were busy knocking off secret British designs for looms and mills, while producers and publishers extensively pirated foreign publications, art, and drama (Khan \& Sokoloff, 2001: 237). The US government 'stood ready to help them' (Raustiala \& Sprigman, 2013: 29).

Even American author Edgar Allan Poe got into the piracy game. The only book Poe published that was successful enough to be reprinted during his lifetime was not House of Usher or Rue Morgue, but The Conchologist's First Book (or A System of Testaceous Malacology, Arranged Expressly for the Use of Schools - a Textbook on Molluscs first published in 1839) (Gould, 1993; Quinn, 1998). This was because Poe and his coauthor plagiarized works by British authors and such plagiarism was quickly discovered. Poe admitted as much in his own writings, but with no international copyright agreement, the original British publisher had no recourse (Gould, 1993).

During Charles Dickens' visit to the United States in 1842, he was appalled by the ubiquitous pirating of his work. He called for better protection of IPR. However, the US media, which regularly pirated British works, serialized novels, and other content, contended that Dickens should be appreciative for his popularity and that he was greedy to complain about his work being pirated (Tomalin, 2011: 128-132).

There was no shortage of British critics such as Dickens who lamented that the American culture - historically centered on lawlessness and rebellion (from a British standpoint) - might have been hopeless in improving IPR protection (Tomalin, 2011). Moreover, painful and fruitless IPR negotiations between Britain and the United States led many British commentators to conclude that Americans were politically unwilling to protect IPR. These cultural and political arguments were similar to those invoked to explain the apparent 'hopelessness' of the recent IPR situation in China.

From an institution-based view, we argue that the US refusal to protect foreign IPR (prior to 1891) was rational. Given the lower levels of literary and economic development, benefits from the protection of foreign IPR would simply accrue to foreign inventors, authors, and firms (such as British publishers), while domestic consumers had to shoulder higher costs for books, media products, and innovative goods. In path dependence terms, institutions such as those supporting the violation of foreign IPR, once in place, would be hard to change (Arthur, 1994). However, institutions do change - as illustrated in the next section.

\section{INSTITUTIONAL TRANSITIONS IN THE UNITED STATES}

Institutions can change (Campbell, 2004). Institutional isomorphism asserts pressures on individuals, organizations, and even nation-states to conform, thus triggering the long-term processes for institutional transitions (DiMaggio \& Powell, 1983). In the long run, development of informal institutions such as clear norms on what are legitimate behaviors can be identified (Scott, 2014). Sometimes, 
'nation-states, subject to only modest coercion or control, adopt standard identities and structural forms' (Meyer, Boli, Thomas, \& Ramirez, 1997: 174). ${ }^{[5]}$ In the IPR arena, nineteenth-century America and twentieth-first-century China did eventually switch from violating to respecting IPR - at least in terms of formal law-making. In 1891, to the pleasant surprise of British critics, the United States voluntarily strengthened its IPR laws with the passing of the International Copyright Act (commonly known as the Chace Act after its sponsor, Senator Jonathan Chace from Rhode Island), which extended IPR protection to foreign works. What was the cause for such a major institutional transition in the US IPR regime?

Foreign (primarily British) pressures played a role behind the enactment of the Chace Act. However, given the repeated US refusals to British demands prior to 1891, such coercion was likely not the main driver of change. A more significant driving force behind such a transformation was likely the pressures from numerous indigenous inventors, authors, and organizations within the United States. As the close of the nineteenth century approached, the United States had turned from being a net consumer to a net producer of intellectual products (Fisher, 1999; Khan \& Sokoloff, 2001, 2004). As more American authors, publishers, and producers were eager to market their products overseas (a leading market was Britain and the British Empire), they naturally desired better IPR protection from foreign governments (Thompson, 1986). However, in the absence of reciprocity, foreign governments were unwilling to grant US rights holders IPR protection. They would only offer IPR protection for US rights holders if the United States offered equivalent protection to non-US IP rights holders in the United States.

Further, in the late nineteenth century, American IP was being increasingly pirated elsewhere - especially in Canada. Similar to the Americans, the Canadians offered IPR protection to domestic (Canadian and British Empire) inventors, authors, and publishers, but did not offer IPR protection to foreigners (essentially Americans). Thus, pirating US publications was widespread in Canada, causing an uproar among American publishers and writers such as Mark Twain. ${ }^{[6]}$ Given these changing winds, it was rational to start offering IPR protection in the United States to foreign authors and inventors. Essentially, the costs of offering local protection to foreign IPR were thought to be outweighed by the benefits of having American IPR protected overseas.

In other words, piracy 'promoted domestic publishing output' in nineteenthcentury America (Khan, 2013: 67, emphasis added). For nineteenth-century America and many developing economies today, strong IPR 'to primarily protect the rights of foreigners hindered their ability to imitate the technologies of the advanced countries and to learn by doing' (Khan, 2013: 68). A cost-benefit analysis suggests that only when the US economy (especially its IP production) was strong enough could the United States afford to offer IPR protection to foreigners (Raustiala \& Sprigman, 2013: 29). Charles Dickens would probably be turning in his grave if he heard that the leading pirating nation of his time, the United States, had become a leading IPR advocate recently. 


\section{THE SWEET AND SOUR HISTORY OF US IPR PROTEGTION ${ }^{[7]}$}

Institutional transitions do not take place over night and do not necessarily unfold in a linear fashion (North, 1990; Scott, 2014). Twists, turns, and setbacks are likely. Even after major transitions such as the 1891 Chace Act, two episodes stand out: (1) the complaint that US patent law was 'over protecting' German chemical firms and (2) the US refusal to protect fashion design as IPR.

\section{US-German Rivalry in the Ghemical Industry}

As two rapidly developing economies, the United States and Germany engaged in strong rivalry prior to 1914 . Competition in the innovation-driven chemical industry was especially intense (Chandler, 1990). Between 1900 and 1910, the United States granted 4,068 patents to chemical and related inventions. Twothirds of them went to four leading German firms - Badische Anilin und SodaFabrik (BASF), Bayer (Farbenfabriken), Hoechst, and IG Farben (Khan, 2013: 64). German firms dominated the market for innovations in dyes and chemicals, and used patent rights to foreclose on US rivals. Many US managers and policymakers complained that when the US chemical industry was still an 'infant industry', such (overly) strong IPR protection of globally competitive German rivals - thanks to the 1891 Chace Act - prevented US firms from producing knock-off products. In short, such 'over protection' made German rivals stronger and conversely the fledgling US firms weaker.

Only the confiscation (without compensation) of German IPR in 1917 consisting of several thousand patents, trademarks, and copyrights as well as German corporate assets - thanks to the US entry into World War I (WWI) and an amendment of the Trading with Enemy Act - did the competitiveness of the US chemical industry improve significantly (Khan, 2013). Specifically, such IPR violation resulted in a $20 \%$ increase in US domestic inventions during and in the aftermath of WWI (Moser \& Voena, 2012). However, despite such a 'windfall stock' of German IPR, the absorptive capacity of US firms was still limited (Khan, 2013: 64). After WWI, German firms were able to regain their former competitive advantage in dyes and chemicals.

\section{US-French Competition in the Fashion Industry}

From the beginning of the fashion industry, France has developed a number of leading firms and the United States has had numerous imitators, copycats, and pirates (Pouillard, 2011). While one can debate the creativity differences between fashion industry practitioners in the two countries, from an important but often overlooked institution-based view, we need to realize the crucial institutional differences governing this industry. French copyright law protected fashion design, while US copyright law did not and still does not offer such protection (Pouillard, 2011). Prior to WWII, making sketches at the Paris fashion openings was forbidden 
by French law. Nevertheless, numerous Americans attended such fashion shows and sketched the designs from memory right after the shows. They then illegally sold such unauthorized copies to American designers in New York, who would start copying the designs immediately.

The efforts made by French fashion houses and their legal US importers (typically high-end retailers) to stop such copying, which was illegal in France but legal in the United States, were difficult. In 1930, a bill outlawing such copying passed the House of Representatives but failed to pass the Senate. Viewed as counter to the American ideal of social equality, the bill, according to its critics, would 'take away from the poor working girl the right to wear the same pattern of goods that the wealthy people do' (Pouillard, 2011: 331). Further, opponents argued that copying pushed American designers to innovate and that such piracy boosted economic growth (Pouillard, 2011: 343-344). Today the debate continues to rage. A recent effort was the Design Piracy Prohibition Act sponsored by Representative Robert Goodlatte from Virginia, which was debated by the US Congress in 2011. But it failed to pass.

\section{Analysis of the Two US Episodes}

Overall, the sweet and sour history of IPR protection in the United States both before and after the enactment of the 1891 Chace Act - has been neither linear nor comprehensive. From an institution-based view, the path dependence of not respecting (certain) foreign IPR is evident in the efforts to expropriate German IPR during WWI and in the continued refusal to protect fashion design at the expense of the French fashion industry. The processes are indeed long term - several decades after 1891 for the chemical industry and over a century (and still ongoing) for the fashion industry. But despite such industry-specific exceptions, generally speaking, post-1891 institutional transitions in IPR protection have certainly resulted in significantly improved IPR protection in the United States.

Informed by the institution-based view, our historical examination has revealed that (1) the United States engaged in significant IPR violation when its economy was taking off, and (2) the development of admittedly better US IPR protection in recent times has been neither linear nor comprehensive. Next, we use the same institution-based lens to shed light on two recent IPR developments in China.

\section{TWO REGENT DEVELOPMENTS IN GHINA}

\section{The Surge of IPR Proclamations, Patenting, and Litigation}

Far from being an IPR 'backwater', since the beginning of the 2000s, China has become one of the most eager countries in promoting innovation and IPR (Abrami et al., 2014; Cao, Li, Li, \& Liu, 2013; Cheng \& Huang, 2016; Hu \& Mathews, 
Table 1. IPR civil cases in China and the United States

\begin{tabular}{lcccc}
\hline \hline & Copyright cases & Trademark cases & Patent cases & Total IPR civil cases \\
\hline China (2010) & 24,700 & 8,460 & 5,785 & 38,945 \\
United States (2010) & 2,192 & 2,792 & 1,674 & 6,658 \\
\hline \hline
\end{tabular}

Source: Extracted from data reported in Suttmeier, R. P., \& Yao, X. 2011. China's IP transition: Rethinking intellectual property rights in a rising China (13). NBR Special Report 29. Seattle: National Bureau of Asian Research.

2008; Lewin et al., 2016; Li, 2012; Liu, Simon, Sun, \& Cao, 2011; Williamson \& Yin, 2014). According to the National Patent Development Strategy (SIPO, 2010):

By 2020, China will become a country with a comparatively high level in terms of the creation, utilization, protection, and administration of patents... The quantity of patents for inventions for every 1 million people, and the quantity of patent applications in foreign countries will quadruple (3)... By 2015, the annual quantity of applications for patents for inventions, utility models and designs will reach 2 million. China will rank among the top two in the world in terms of the annual number of patents on inventions granted to domestic applicants and the quality of patents filed will further improve (4).

Despite the overwhelmingly negative Western media coverage of IPR violation in China, it is difficult to argue that the Chinese government is not serious about IPR (Cao et al., 2013; Hu \& Mathews, 2008; Lewin et al., 2016; Yu, 2008). Total patent applications in China jumped from 476,000 in 2005 to over 1.2 million in 2010 (Suttmeier \& Yao, 2011: 13). Today China is the world champion in the number of patent applications (The Economist, 2014: 73). While the quality of Chinese patents (such as numerous alleged 'junk patents') may be questioned (Cheng \& Huang, 2016; The Economist, 2014), some scholars suggest that it 'may not be a serious concern' (Li, 2012: 236; see Boeing, Mueller, \& Sander, 2016). ${ }^{\left[{ }^{8]}\right.}$ At least in terms of volume, China's patent system 'has arguably accomplished what no other patent system in the world has ever achieved' (Yu, 2013: 88).

Given the domestic and international complaints about the lack of IPR expertise among judges, China has recently set up a system of specialized IP courts led by judges specifically trained in IPR enforcement. As a result, IPR litigation has skyrocketed. Table 1 shows 38,945 IPR civil cases in 2010 (most of which involving Chinese plaintiffs suing other alleged Chinese IPR violators). ${ }^{[9]}$ In comparison, the United States had 6,658 such cases. In 2013, the number of IPR case adjudicated in China reached over 100,000 (McKinsey, 2015: 115). China has become the world's most litigious country with respect to IPR - measured by the number of IPR litigation cases (Suttmeier \& Yao, 2011: 13). 


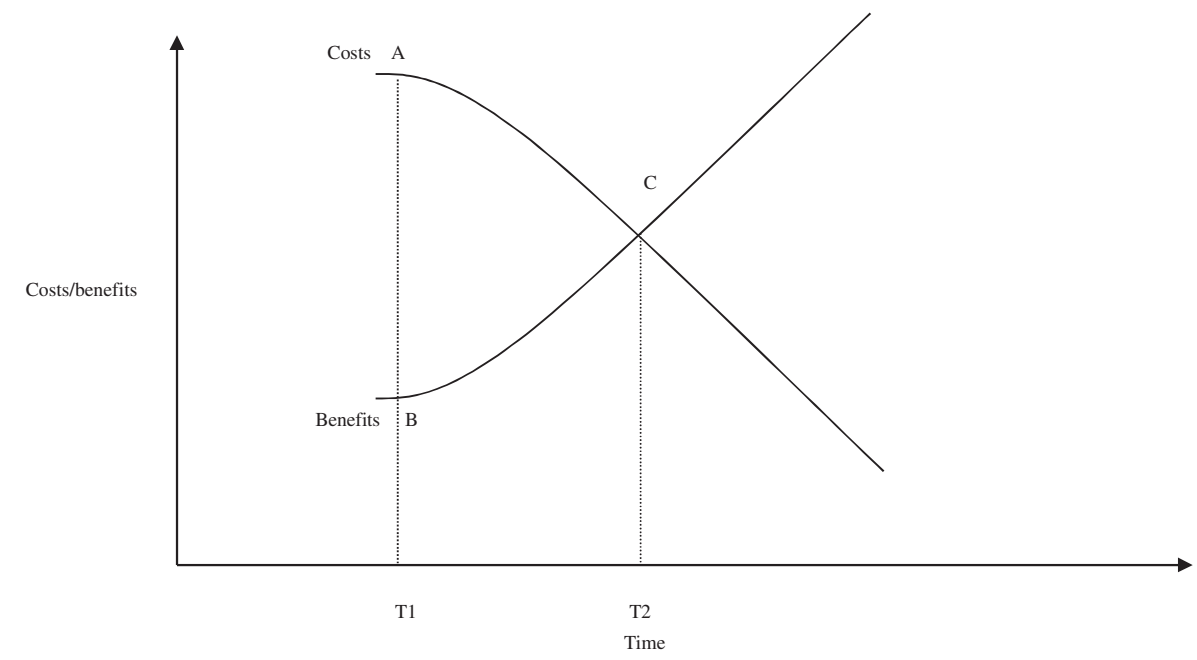

Figure 1. The costs and benefits of IPR protection and enforcement institutions

\section{Analysis of China's Surge of IPR Proclamations, Patenting, and Litigation}

What can explain China's transformation from long-time reluctance to recent eagerness in promoting IPR? From an institution-based view, this development deviates from path dependence. This is why it is labeled 'counterintuitive' by Suttmeier and Yao (2011: 5). Historical forces generally constrain contemporary laws and practices to be similar to past ones (Klochikhin, 2012). But exogenous influences and endogenous changes to institutions are possible and can modify a seemingly entrenched path (Greif \& Laitin, 2004).

As the self-reinforcing aspects of the informal institutional regime are gradually undermined by changes in the environment, both endogenous and exogenous changes are enabled. One endogenous element of this change in the United States was paradoxically a push by the railroads in the 1870s to make patenting more difficult and narrow (Usselman, 1999). Some inventions were thought to be small incremental changes and should fall under the purview of trade secrets within firms and not IP. This debate eventually did lead to the tightening of IP laws, in spite of the railroads' protests. China has started to experience similar debates about IP and its optimal scope given its current level of development (Suttmeier \& Yao, 2011).

The long-term institutional processes of enhancing legitimacy have asserted their influence - thanks to foreign pressures as well as an increase in invention by firms and citizens and gradual recognition from the public of its value (Sokoloff \& Khan, 1990). This increasingly accumulated momentum and court cases have led to a gradual appreciation of the wider benefits of strengthened IPR protection.

Over time, the cost-benefit analysis underpinning institutional transitions becomes evident (Greif \& Laitin, 2004; Peng, 2003). Figure 1 illustrates the costs and benefits of IPR protection and enforcement institutions. Setting up 
such institutions is costly. During time 1, the costs of better IPR protection and enforcement outweigh the benefits - at least viewed from the perspective of domestic Chinese firms (a situation almost identical to nineteenth-century America). Over time, both the Chinese government and firms have realized more sustained economic growth will increasingly need to draw on IPR (Cao et al., 2013; Lewin et al., 2016; Liu et al., 2011). Past time 2 (the proverbial 'crossover point' [Yu, 2013] or 'point of inflection' [Peng, 2003]), enhanced IPR protection and enforcement will be more beneficial, thus motivating the emergence of stronger IPR institutions (such as specialized IPR courts), which in turn fuel the more extensive use of these institutions (as evidenced by the rising number of IPR litigation cases). In sum, institutional transitions fostering stronger IPR in a country known for IPR violation is possible - as long as stakeholders such as policymakers, managers, consumers, lawyers, and judges believe they can 'do better' in a new environment (North, 1990: 8).

\section{The Promotion of 'Indigenous Innovation'}

If the first new development of improved and widely accepted IPR institutions is encouraging, a second development - the Chinese government's promotion of 'indigenous innovation' - has attracted significant criticism, especially from the international business community (IP Commission, 2013; USTR, 2010). China's first ever National Patent Development Strategy stated:

The level of self-relied intellectual property will be higher by a large margin and the quantity of intellectual property will be greater. China will rank among the advanced countries of the world in terms of the annual number of patents for inventions granted to the domestic applicants, while the number of overseas patent applications filed by Chinese applicants should greatly increase. A number of world-famous brands will emerge. The proportion of the GDP accounted for by the value of core copyright industries will greatly increase (SIPO, 2010: 2).

Such an explicit emphasis on indigenous innovation has been criticized by US and foreign rights holders as well as their governments. These sentiments are summarized by the US Trade Representative in the 2010 National Trade Estimate Report on Foreign Trade Barriers:

A troubling trend that has emerged... is China's willingness to encourage domestic or 'indigenous' innovation at the cost of foreign innovation and technologies... In order to qualify as 'indigenous' innovation under the accreditation system, and therefore be entitled to procurement preferences, a product's intellectual property must originally be registered in China (USTR, 2010: 69). 


\section{Analysis of China's Promotion of 'Indigenous Innovation'}

The institution-based view can again contribute to a better understanding of this development. First, just like the case of US chemical and fashion industries, the path dependent nature of protecting domestic firms in certain industries is hard to break off from in China - even after significant commitments are made to enhance IPR protection (Howell, 2015).

Second, being aware of the long-term processes, we caution against a 'knee-jerk' reaction of harsh criticism (as reflected in USTR [2010]). Instead, we advocate a more nuanced reading of history. Specifically, history suggests that US policies regarding foreign IPR during much of the nineteenth century (prior to the 1891 Chace Act) can be regarded as US 'indigenous innovation policies'. One lesson from history is that such policies 'may help encourage the development of local stakeholders' as advocates of stronger IPR protection and enforcement (Yu, 2013: 91; see also Jandhyala, 2015: 287). Recall that it was the emergence of a critical mass of indigenous stakeholders such as US publishers, authors (such as Mark Twain), and inventors (such as Eli Whitney), who decisively pushed the US government to promote stronger IPR protection. Encouragingly, a new generation of indigenous stakeholders interested in better IPR protection is emerging in China. Jack Ma, founder of Alibaba, has called counterfeit goods a 'cancer' and vowed to mobilize both Alibaba and other stakeholders to fight counterfeit goods (The Economist, 2016: 52).

Finally, an interest in fostering institutional transitions offers a counterintuitive suggestion that the US government, US rights holders, as well as the international business community assist China to strengthen its indigenous innovation policies. This is because fostering China's indigenous innovation policies is compatible with initiating cognitive beliefs about the value of IPR and the need to protect it. It is also compatible with the long-run goal of improving IPR protection for all firms in China - both Chinese and foreign. To do this, foreign governments can help the Chinese government to create more uniform IPR laws and encourage their consistent enforcement around the country (Poncet, 2005).

\section{DISGUSSION}

\section{Contributions}

This article endeavors to respond to calls for organizational researchers to address broader, bigger issues of our times (Davis, 2015; Lewin, 2015). Overall, at least two contributions emerge. First, we join Peng et al. (2017) in demonstrating how history can be directly relevant in informing a crucial, ongoing debate. History can help to identify patterns and parallels that can inform present day explanations and provide potential propositions for future research, practice, and policy (Ferguson, 1999). For example, Weber studied the history of the Roman Legions, the Prussian Army, and the Roman Catholic Church to develop his theory about effective 
organizing (Weber, Baehr, \& Wells, 2002). Chandler (1990) advocated research on firm strategy and structure by investigating major industrial firms in Britain, Germany, and the United States. Military history has long influenced the analysis and formulation of strategy (Ahlstrom et al., 2009). Extending such traditions of history research, our article suggests that historical variation is an important complement to contemporary cross-sectional variation in articulating conceptual issues (Jones \& Khanna, 2006). Our approach also resonates with the recent call for an international comparison in better understanding how history matters (Friedman \& Jones, 2011).

How generalizable is the American experience in the nineteenth century to today's China? Although the United States and China differ on a number of dimensions, the international exchange and diffusion of ideas and practices have scaled new heights recently (Paulson, 2015). Neither of these two countries nor any other country for that matter - can evolve its own IPR institutions in total isolation. Institutional systems, especially formal ones, can have considerable influence on each other. ${ }^{[10]}$ If we embrace a more global and longer view of history, we see that documented IPR violation started at least during the Roman times (Chaudhry \& Zimmerman, 2009), and that new laws and their enforcement contributed to improvements of IPR (Raustiala \& Sprigman, 2012; Yu, 2014a).

Second, by addressing and leveraging a specific episode of history, this article also enriches the institution-based view (Ahuja \& Yayavaram, 2011; Meyer \& Peng, 2016; Peng et al., 2008, 2009). Our historical excursion identifies the distinction and similarities in the course of events across time and location (Kieser, 1994). Some have argued that culture, and particularly Confucianism, is linked to weak IPR protection (Alford, 1995). Our historical examination has revealed similar culture-based arguments made about a US 'frontier culture' of lawlessness in the appropriation of IP in the nineteenth century. Few would make the argument about a lawless frontier culture in US IPR today - except in the area of fashion where some French fashion houses continue to complain (Pouillard, 2011). In spite of the concerns about IPR, China has clearly made strides in recent years.

Specifically, we argue that economic development in China will facilitate improved IPR protection as economic development in the United States did in the nineteenth century. The poorest countries allocate few resources to innovation and thus have little IPR to protect. As incomes grow to middle income levels, some inventive capacity tends to emerge, but competition remains based on imitation. As a result, the majority of economic and political interests prefer weak IPR protection. As an economy develops further, additional inventive capacity and demands for high-quality products emerge, and commercial lobbies form to demand effective protection - a domestic interest that coincides with the foreign interest in better IPR protection.

In summary, organizational research that addresses historical context is beneficial to theory development. This is because it does not allow complex phenomena such as the development IPR protection to be automatically attributed 
to culture or some other latent variable with little further explanation (Singh, 2007), while avoiding limited, episodic understandings of such phenomena. By studying the history of IPR development in the United States, we can better identify and explain the potential parallels to China's current and future IPR development.

\section{Policy and Practical Implications}

Several public and business policy implications emerge (Khoury \& Peng, 2011; Paulson, 2015). In terms of public policy, Raustiala and Sprigman suggest that 'the United States should consider its own history as a pirate nation - and relax' (2013: 30). With an historical mindset, it is possible to appreciate that the differences between the United States and China in the IPR debate are not as significant as certain media and trade groups may portray. A practical lesson from a greater appreciation of history is to look for similarities that can help overcome the differences (Yu, 2011).

However, it is important to point out that certain groups benefit from an environment where the differences between the United States and China are magnified. 'The more differences there are, the more valuable their expertise will become, and the more they can influence the policy and business debate' (Yu, 2011: 1128). When these differences are sharpened, important areas of potential cooperation - such as those dealing with China's indigenous innovation policies become difficult. 'The two countries will be worse off as a result' (Yu, 2011: 1128; see also Paulson, 2015).

Policymakers in China and other developing countries need to better arm themselves with a good command of the historical knowledge and to be aware of the crossover point - the point of inflection beyond which benefits will outweigh the costs of world-class IPR protection. The WTO requires that developing countries raise their IPR levels to the standard in force in more developed countries at the time of negotiation. However, by examining the welfare implications of protecting IPR and bringing technology transfer and tariffs into the equation, Naghavi (2007) argues that prior to the crossover point, following the highest standards in IPR protection is not necessarily ideal.

US managers who complain about IPR violation in China today can learn how British authors, composers, and firms dealt with counterfeiters in the United States and elsewhere over 100 years ago. 'Litigation was normally a last resort. Private agreements with offenders were cheaper and quicker, both because they could be kept confidential and because they avoided unduly alarming consumers about quality or alerting them to the possibility of purchasing a substitute at a cheaper price' (Lopes \& Casson, 2012: 303). For example, nineteenth-century British composers Gilbert and Sullivan brought their entire troupe to New York to perform The Pirates of Penzance, and thus upstaged the theatrical pirates who had made so much money (without paying any royalties) from pirating Gilbert and Sullivan's previous smash hit, HMS Pinafore (Gould, 1993). In contemporary China, 
numerous multinationals have been able to adapt to the Chinese IPR system and maximize their performance, leveraging a Gilbert-and-Sullivan-style pre-emptive strategy by bringing the innovation to China very early in its development (Liang \& Xue, 2010). Specifically, they file patents and trademarks - including Chineselanguage trademarks - as soon as possible, and/or set up strategic alliances with dependable Chinese partners right away (Shi, Sun, Pinkham, \& Peng, 2014). Such aggressive activities in China 'makes major patent infringement very difficult' (Liang \& Xue, 2010: 491).

Managers in China who are currently involved in IPR violation need to be aware of the rapidly evolving institutional transitions toward better IPR protection. Although a 'copycat' strategy centered on IPR violation has been viable (Shenkar, 2010), institutional transitions may make this strategy obsolete. The best managers expect strategy to shift over time by constantly deciphering changes in the 'big picture' (Peng, 2003). That is why a good command of the historical knowledge of IPR evolution elsewhere in the world can be helpful. As institutional transitions unfold, the highest-performing firms seem to be those that convert the gains from an earlier strategy centered on IPR violation into value-adding capabilities that thrive on innovation. For example, Huawei, which was sued by Cisco for alleged IPR violation in 2003, has emerged as a leading innovator. It now routinely files one of the largest numbers of international patents among all firms in the world. On the other hand, 'firms that fail to realize the passing of their time are likely to fall behind or go out of business' (Peng, 2003: 292).

\section{Limitations and Future Research Directions}

We have barely scratched the surface of IPR development in the United States, China, and elsewhere around the world. We have neither covered IPR development in other parts of today's developed economies (those in Europe such as Great Britain and Germany and those in Asia such as Japan and Korea), nor that in other parts of developing economies (such as Brazil and India). Following Peng et al. (2017), new insights will certainly emerge when future historically oriented IPR research probes these areas.

Similarly, future research should also address abstract arguments about culture and its impact on important institutional variables. For example, the more abstract argument about a Confucian value system driving a unique form of Chinese IPR as some commentators have argued does not stand up well to either historical or analytical scrutiny. In particular, it fails to distinguish between Confucianism and a range of ethical teachings that have also influenced and continue to influence China's legal system and cultural milieu such as Taoism and Buddhism. The teachings in these systems are not in harmony with one another when it comes to IPR and other aspects of organizing (Ahlstrom \& Wang, 2010). This is not to say that culture does not matter, but scholars must be careful not to rush to cultural 
explanations before examining historical parallels, institutional developments, and other key processes that may be largely distinct from cultural values (Singh, 2007).

\section{GONGLUSION}

How can history inform the debate on IPR? How can organizational scholars add to such an important debate? In short, history can be used both to understand the past and the present better and to make difficult decisions concerning the future in a more informed way (Neustadt \& May, 1986). Instead of strict path dependence, cultural determinism, or basic episodic assessment history helps to explain the past and the present, and suggests possible future directions given institutional constraints by assessing present-day events historically (Draper, 1996; North, 1990). Joining Peng et al. (2017), this article has extended the institutionbased view by demonstrating how the history of the United States transforming itself from a leading IPR violator to a leading IPR champion can be used to inform the contemporary US-China debate on IPR. Leveraging this period of US history, we predict that to the same extent that the United States voluntarily agreed to strengthen IPR protection when the US economy became sufficiently innovationdriven, China will similarly enhance its IPR protection. We further predict that when Chinese IPR are significantly violated abroad, China will become more serious about IPR protection. Therefore, we suggest that China's indigenous innovation policies need to be strengthened instead of discouraged by foreign IP rights holders, governments, and other stakeholders.

\section{NOTES}

We thank Arie Lewin (Editor-in-Chief) for his encouragement and guidance. Earlier versions were presented at AAOM (Hong Kong, 2015); Copenhagen Business School; Hong Kong Baptist; HKUST; IACMR (Beijing, 2014; and Hangzhou, 2016); Renmin; Seattle; Shanghai Jiao Tong; Simon Fraser; Stockholm; Tsinghua; Universities of Newcastle, San Francisco, Sydney, and Texas at Dallas; Western Washington; and Xi'an Jiaotong. We thank Kevin Au, Michael Bond, Xiaoping Chen, Ping Deng, Tony Fang, Sam Garg, Steve Globerman, Syd Gray, Siggi Gudergan, Michael Jacobsen, Kwok Leung, J. T. Li, Jing Li, John Li, Peter Li, John Lin, Klaus Meyer, Bo Nielson, David Reid, Tom Roehl, Danny Shapiro, Pek-Hooi Soh, Hao Tan, Alain Verbeke, Cristina Vlas, David Whetton, Zhengzheng Xie, Xiaohua Yang, Jingtao Yi, Michael Young, Wu Zhan, and Jing Zhao for helpful discussions. This research has been supported by the Jindal Chair at UT Dallas.

[1] While we focus on China, numerous other countries have also been implicated by the United States Trade Representative (USTR, 2010) as IPR violators, such as Argentina, Brazil, Chile, Egypt, India, Israel, Mexico, Paraguay, Russia, Thailand, Turkey, Ukraine, and Venezuela (Chaudhry \& Zimmerman, 2009).

[2] For example, the Roman writer Vitruvius (257-180 BCE) revealed IP theft during a literary contest in Alexandria. While serving as a judge in the contest, Vitruvius determined that some poets in the contest had stolen the words and phrases of other writers. After being found out, the false poets were then tried, convicted, and disgraced (Bugbee, 1967). Yet in spite of such occasional prosecutions in Rome and later in medieval Europe, there were few laws codifying IP protection in Roman and medieval times, and the prosecution of offenses tended to be ad hoc (Bugbee, 1967).

[3] While we leverage the US experience, it is important to note that Germany, Japan, and numerous other developed countries were also significant IPR violators when their economies were taking off. However, 'all the major imitators subsequently became leading economic powers, indicating an apparent connection between learning by imitation and economic growth' (Lopes \& Casson, 2012: 308). 
[4] American inventors sometimes found their inventions violated by their countrymen as well. For example, Eli Whitney invented the Cotton Gin in 1793 and patented it in 1794 under America's new Patent Law. Although this invention revolutionized the US cotton industry, it proved impossible to enforce as competent carpenters were able to rapidly produce and sell knock-off Cotton Gins. Whitney spent years pursuing patent lawsuits, and not until 1807 was the patent properly enforced. Whitney would realize only about $\$ 100,000(\$ 2,000,000$ today). Much of the money was donated from southern state governments thankful for his invention (Gordon, 2005).

[5] In addition to IPR, another visible area of long-term institutional isomorphism is the adoption of democracy, which has spread from 69 countries in the 1980 s to 120 in the 2000s.

[6] Mark Twain had to establish residency in Canada in order to protect the copyright of his novel The Prince and the Pauper in Canada. Given the costs involved, few authors could possibly afford to do that.

[7] This title is inspired by Yu's (2014b) title: 'The sweet and sour story of Chinese intellectual property rights'.

[8] The quality of many US patents can be similarly questioned. For example, Business Week (2006: 60) reports that the United States is 'awash in a sea of junk patents'.

[9] In China, about 3\% of all recent civil IPR litigation involved a foreign party (Suttmeier \& Yao, 2011:34).

[10] For example, California contract law in terms of investment term sheets and related contractual agreements has impacted the practice and rules regarding venture capital and start-up firms around the world - including those in China (Ahlstrom, Bruton, \& Yeh, 2007; Bruton \& Ahlstrom, 2003).

\section{REFERENCES}

Abrami, R. M., Kirby, W. C., \& McFarlan, F. W. 2014. Why China can't innovate: And what it's doing about it. Harvard Business Review, 92(3): 107-111.

Ahlstrom, D., Bruton, G. D., \& Yeh, K. S. 2007. Venture capital in China: Past, present, and future. Asia Pacific Journal of Management, 24(3): 247-268.

Ahlstrom, D., Lamond, D., \& Ding, Z. 2009. Reexamining some management lessons from military history. Asia Pacific Journal of Management, 26(4): 617-642.

Ahlstrom, D., \& Wang, L. C. 2009. Groupthink and France's defeat in the 1940 campaign.Journal of Management History, 15(2): 159-177.

Ahlstrom, D., \& Wang, L. C. 2010. Entrepreneurial capitalism in East Asia: How history matters. In H. Landström \& F. Lohrke (Eds.), The historical foundations of entrepreneurial research: 406-428. Cheltenham, UK: Edward Elgar.

Ahuja, G., \& Yayavaram, S. 2011. Explaining influence rents: The case for an institution-based view of strategy. Organization Science, 22(6): 1631-1652.

Alford, W. P. 1995. To steal a book is an elegant offense: Intellectual property laze in Chinese civilization. Stanford, CA: Stanford University Press.

Arthur, W. B. 1994. Increasing returns and path dependence in the economy. Ann Arbor, MI: University of Michigan Press.

Barley, S. R. 2016. Ruminations on how we became a mystery house and how we might get out. Administrative Science Quarterly, 61: 1-8.

Boeing, P., Mueller, E., \& Sander, P. 2016. China's R\&D explosion: Analyzing productivity effects across ownership types and over time. Research Policy, 45(1): 159-176.

Bruton, G. D., \& Ahlstrom, D. 2003. An institutional view of China's venture capital industry: Explaining the differences between China and the West. Journal of Business Venturing, 18(2): 233-259.

Bugbee, B. 1967. The genesis of American patent and copyright laze. New York: Public Affairs Press.

BusinessWeek. 2006. The patent epidemic. January 9: 60-62.

Campbell, J. L. 2004. Institutional change and globalization. Princeton, NJ: Princeton University Press.

Cao, C., Li, N., Li, X., \& Liu, L. 2013. Reforming China's S\&T system. Science, 341(August 2): $460-462$. 
Chandler, A. D. 1990. Strategy and structure: Chapters in the history of the industrial enterprise. Boston: MIT press.

Chaudhry, P. E., \& Zimmerman, A. 2009. The economics of counterfeit trade. Heidelberg, Germany: Springer.

Cheng, M. L., \& Huang, C. 2016. Transforming China's IP system to stimulate innovation. In A. Y. Lewin, M. Kenney \& J. P. Murmann (Eds.), China's innovation challenge: Overcoming the middle-income trap: 152-188. New York: Cambridge University Press.

Chow, D. G. K. 2003. The legal system of the People's Republic of China in a nutshell. St. Paul, MN: West.

David, P. 1985. Clio and the economics of QWERTY. American Economic Revieze, 75(2): 227332.

Davis, G. F. 2015. What is organizational research for? Administrative Science Quarterly, 60(2): $179-188$.

DiMaggio, P.J., \& Powell, W. W. 1983. The iron cage revisited: Institutional isomorphism and collective rationality in organizational fields. American Sociological Revieze, 48(2): 147160.

Draper, T. 1996. A struggle for pozer: The American Revolution. New York: Times Books.

Feng, N. H. 2007. To steal a book is just an elegant offense? Discussion on books' copyright protection in imperial China. Library and Information Service, 51(11): 58-61.

Ferguson, N. (Ed.). 1999. Virtual history: Alternatives and counterfactuals. New York: Basic Books.

Fisher, W. W. 1999. The growth of intellectual property: A history of the ownership of ideas in the United States. Working paper, Harvard Law School. [Cited 15 July 2016]. Available from URL: www.cyber.law.harvard.edu

Friedman, W. A., \& Jones, G. 2011 . Business history: Time for debate. Business History Revieze, 85(1): 1-8.

Galtsova, P. 2008. Intellectual property reform in Russia: Analysis of part four of the Russian Civil Code. Master's thesis, Faculty of Law, Lund University, Sweden.

Gordon, J. S. 2005. Empire of wealth: The epic history of American economic pozer. New York: Harper Perennial.

Gould, S. J. 1993. Poe's greatest hit. Natural History, 102(7): 10-19.

Greif, A., \& Laitin, D. 2004. A theory of endogenous institutional change. American Political Science Revieze, 98(4): 633-652.

Hall, P. A., \& Taylor, R. 1996. Political science and the three new institutionalisms. Political Studies, 44: 936-957.

Hill, C. W. L. 2007. Digital piracy: Causes, consequences, and strategic responses. Asia Pacific Journal of Management, 24(1): 9-25.

Hofstede, G. 2007. Asian management in the $21^{\text {st }}$ century. Asia Pacific Journal of Management, 24(4): 411-420.

Howell, A. 2015. Indigenous innovation with heterogeneous risk and new firm survival in a transitioning Chinese economy. Research Policy, 44(10): 1866-1876.

Hu, M.-C., \& Mathews, J. A. 2008. China's national innovation capacity. Research Policy, 37(9): $1465-1479$.

Ingram, P., \& Silverman, B. 2002. Introduction. In P. Ingram \& B. Silverman (Eds.), The neze institutionalism in strategic management: 1-30. Amsterdam: Elsevier.

IP Commission, The (The Commission on the Theft of American Intellectual Property). 2013. The IP commission report. Seattle: National Bureau of Asian Research.

Jaffe, A. B., \& Lerner, J. 2007. Innovation and its discontents. Princeton, NJ: Princeton University Press.

Jandhyala, S. 2015. International and domestic dynamics of intellectual property protection.Journal of World Business, 50(2): 284-293.

Johns, A. 2009. Piracy: The intellectual property wars from Gutenberg to Gates. Chicago: University of Chicago Press.

Jones, G., \& Khanna, T. 2006. Bringing history (back) into international business. Journal of International Business Studies, 37(4): 453-468.

Khan, B. Z. 2005. The democratization of invention: Patents and copyrights in American economic development, 1790-1920. New York: Cambridge University Press.

Khan, B. Z. 2013. Selling ideas: An international perspective on patenting and markets for technological innovations, 1790-1930. Business History Reviez, 87(1): 39-68. 
Khan, B. Z., \& Sokoloff, K. L. 2001. The early development of intellectual property institutions in the United States. Journal of Economic Perspectives, 15(3): 233-246.

Khan, B. Z., \& Sokoloff, K. L. 2004. Institutions and democratic invention in nineteenth-century America. American Economic Revieze, 94(2): 395-401.

Khoury, T., \& Peng, M. W. 2011 . Does institutional reform of intellectual property rights lead to more inbound FDI? Evidence from Latin America and the Caribbean.Journal of World Business, 46(3): 337-345.

Kieser, A. 1994. Why organization theory needs historical analyses - and how this should be performed. Organization Science, 5(4): 608-620.

Klochikhin, E. A. 2012. Russia's innovation policy: Stubborn path-dependencies and new approaches. Research Policy, 41(9): 1620-1630.

Kumar, N. 2003. Intellectual property rights, technology, and economic development: Experiences of Asian countries. Economic and Political Weekly, January 18: 209-226.

Lewin, A. Y. 2015. Letter from the editor. Management and Organization Revieze, 11(1): $1-3$.

Lewin, A. Y., Kenney, M., \& Murmann, J. P. (Eds.). 2016. China's innovation challenge: Overcoming the middle-income trap. New York: Cambridge University Press.

Li, S. 2004. Why is property right protection lacking in China? An institutional explanation. California Management Revieze, 46(3): 100-115.

Li, X. 2012. Behind the recent surge of Chinese patenting: An institutional view. Research Policy, 41(1): 236-249.

Liang, Z., \& Xue, L. 2010. The evolution of China's IPR system and its impact on the patenting behaviors and strategies of multinationals in China. International Journal of Technology Management, 51(5): 469-496.

Liu, F., Simon, D. F., Sun, Y., \& Cao, C. 2011. China's innovation policies: Evolution, institutional structure, and trajectory. Research Policy, 40(7): 917-937.

Lohr, S. 2002. The intellectual property debate takes a page from 19th-century America. Neze York Times, October 14.

Lopes, T. D. S., \& Casson, M. 2012. Brand protection and the globalization of British business. Business History Revieze, 86(2): 287-310.

Lubman, S. 1999. Bird in a cage: Legal reform in China after Mao. Stanford, CA: Stanford University Press.

Marquis, C., \& Raynard, M. 2015. Institutional strategies in emerging markets. Academy of Management Annals, 9(1): 291-335.

Mazzoleni, R., \& Nelson, R. R. 1998. The benefits and costs of strong patent protection: A contribution to the current debate. Research Policy, 27(3): 273-284.

McCloskey, D. N. 2016. Bourgeois equality: Howe ideas, not capital or institutions, enriched the world. Chicago: University of Chicago Press.

McKinsey Global Institute (McKinsey). 2015. The China effect on global innovation. Report.

Mertha, A. G. 2007. The politics of piracy: Intellectual property in contemporary China. Ithaca, NY: Cornell University Press.

Meyer, J. W., Boli, J., Thomas, G. M., \& Ramirez, F. O. 1997. World society and the nation-state. American Journal of Sociology, 103(1): 144-181.

Meyer, K. E., \& Peng, M. W. 2016. Theoretical foundations of emerging economy business research. Journal of International Business Studies, 47(1): 3-22.

Moser, P. 2013. Patents and innovation: Evidence from economic history.Journal of Economic Perspectives, 27(1): 23-44.

Moser, P., \& Voena, A. 2012. Compulsory licensing: Evidence from the Trading with the Enemy Act. American Economic Revieze, 102(2): 396-427.

Naghavi, A. 2007. Strategic intellectual property rights policy and North-South technology transfer. Revieze of World Economics, 143(1): 55-78.

Neustadt, R. E., \& May, E. R. 1986. Thinking in time: The uses of history for decisionmakers. New York: Free Press.

North, D. G. 1990. Institutions, institutional change, and economic performance. New York: Norton.

Paulson, H. 2015. Dealing with China: An insider unmasks the neze economic superpozer. New York: Grand Central.

Peng, M. W. 2003. Institutional transitions and strategic choices. Academy of Management Reviez, 28(2): 275-296. 
Peng, M. W. 2013. An institution-based view of IPR protection. Business Horizons, 56(2): 135139.

Peng, M. W., Ahlstrom, D., Carraher, S. M., \& Shi, W. 2017. An institution-based view of global IPR history. Journal of International Business Studies, forthcoming.

Peng, M. W., Sun, S. L., Pinkham, B., \& Chen, H. 2009. The institution-based view as a third leg for a strategy tripod. Academy of Management Perspectives, 23(4): 63-81.

Peng, M. W., Wang, D. Y. L., \& Jiang, Y. 2008. An institution-based view of international business strategy: A focus on emerging economies. Journal of International Business Studies, 39(5): 920-936.

Pierson, P. 2004. Politics in time: History, institutions, and social analysis. Princeton, NJ: Princeton University Press.

Poncet, S. 2005. A fragmented China: Measure and determinants of Chinese domestic market disintegration. Revieze of International Economics, 13(3): 409-430.

Pouillard, V. 2011. Design piracy in the fashion industries of Paris and New Yorkin the interwar years. Business History Revieze, 85(2): 319-344.

Quinn, A. H. 1998. Edgar Allan Poe: A critical biography. Baltimore, MD: Johns Hopkins University Press.

Raustiala, K., \& Sprigman, C. 2012. The knockoff economy: How imitation sparks innovation. New York: Oxford University Press.

Raustiala, K., \& Sprigman, C. 2013. Fake it till you make it: The good news about China's knockoff economy. Foreign Affairs, 92(4): 25-30.

Robinson, R. 2016. How Google stole the work of millions of authors. Wall Street Journal, February 8.

Scott, W. R. 2014. Institutions and organizations: Ideas, interests, and identities. Thousand Oaks, CA: Sage.

Shenkar, O. 2010. Copycats: How smart companies use imitation to gain a strategic edge. Boston: Harvard Business School Press.

Shi, W., Sun, S. L., Pinkham, B. C., \& Peng, M. W. 2014. Domestic alliance network to attract foreign partners: Evidence from international joint ventures in China. Journal of International Business Studies, 45(3): 338-362.

Simon, H. A. 1961. Administrative behavior (2nd ed.). New York: Macmillan.

Singh, K. 2007. The limited relevance of culture to strategy. Asia Pacific Journal of Management, 24(4): 421-428.

Sokoloff, K. L., \& Khan, B. Z. 1990. The democratization of invention during early industrialization: Evidence from the United States, 1790-1846. Journal of Economic History, 50(2): 363378.

State Intellectual Property Office (SIPO). 2010. National patent development strategy (20112020). Beijing: SIPO.

Steinmo, S., Thelen, K., \& Longstreth, F. (Eds.) 1992. Structuring politics: Historical institutionalism in comparative analysis. Cambridge: Cambridge University Press.

Suttmeier, R. P., \& Yao, X. 2011. China's IP transition: Rethinking intellectual property rights in a rising China. NBR Special Report 29. Seattle: National Bureau of Asian Research.

The Economist. 2014. Intellectual property in China: Patent fiction. December 13: 73-74.

The Economist. 2016. Counterfeiting and piracy: Stamping it out. April 23: 51-52.

Thompson, K. 1986. Exporting entertainment: America in the zeorld film market, 19071934. London: British Film Institute.

Tomalin, C. 2011 . Charles Dickens: A life. New York: Viking.

US Trade Representative (USTR). 2010. National trade estimate report on foreign trade barriers. Washington, DC: USTR.

Usselman, S. 1999. Patents, engineering professionals, and the pipelines of innovation: The internalization of technical discovery by nineteenth-century American railroads. In N. R. Lamoreaux, D. M. G. Raff, \& P. Temin (Eds.), Learning by doing in markets, firms, and countries: 61-102. Chicago: University of Chicago Press.

Weber, M., Baehr, P. R., \& Wells, G. C. 2002. The Protestant ethic and the 'spirit' of capitalism and other zritings. New York: Penguin Books.

Williamson, O. E. 1985. The economic institutions of capitalism. New York: Free Press.

Williamson, P.J., \& Yin, E. 2014. Accelerated innovation: The new challenge from China. MIT Sloan Management Review, 55(4): 27-34. 
Wren, D. 1987. Management history: Issues and ideas of teaching and research. Journal of Management, 13(2): 339-350.

Yu, P. K. 2008. Intellectual property, economic development, and the China puzzle. In H. C. Hansen (Ed.), Intellectual property law and policy: 990-1023. Portland, OR: Hart Publishing.

Yu, P. K. 2011. The TRIPS enforcement dispute. Nebraska Law Review, 89: 1046-1131.

Yu, P. K. 2013. Five oft-repeated questions about China's recent rise as a patent power. Cardozo Law Review de Novo, 78-114.

Yu, P. K. 2014a. The curious case of fake Beijing Olympics merchandise. In I. Calboli \& E. Lee (Eds.), Trademark protection and territoriality challenges in a global economy: 259-282. Cheltenham, UK: Edward Elgar.

Yu, P. K. 2014b. The sweet and sour story of Chinese intellectual property rights. In G. Dutfeld \& U. Suthersanen (Eds.), Technology, progress, and prosperity. London: Palgrave Macmillan.

Zimmerman, A. 2013. Contending with Chinese counterfeits: Culture, growth, and management responses. Business Horizons, 56(2): 141-148.

Mike W. Peng (mikepeng@utdallas.edu), PhD, University of Washington, is the Jindal Chair of Global Strategy at the University of Texas at Dallas. He is a National Science Foundation CAREER Award winner, a Fellow of the Academy of International Business, and an IACMR Scholarly Contribution Award winner. The Asia Pacific Fournal of Management has named its best paper award the Mike Peng Best Paper Award. He has authored Global Strategy, Global Business, and Global, which are available in Chinese, Portuguese, and Spanish, and used in over 30 countries.

David Ahlstrom (ahlstrom@baf.cuhk.edu.hk), PhD, New York University, is a professor at The Chinese University of Hong Kong. He has published numerous articles in journals such as the Strategic Management fournal, Academy of Management Review, Journal of International Business Studies, and Entrepreneurship: Theory \& Practice. His work has also appeared multiple times in The Wall Street fournal. He co-authored the textbook International Management: Strategy and Culture in the Emerging World. David has also guest edited four special issues of Asia Pacific Journal of Management and two special issues of Entrepreneurship: Theory \& Practice.

Shawn M. Carraher (shawn.carraher@utdallas.edu), PhD, University of Oklahoma, has served as Division Chair of Management History and Technology \& Innovation Management (TIM) within the Academy of Management, President of the Small Business Institute and the Southwestern Academy of Management, and Dean of the Endowed Chairs and Past Division Chairs Committee within the AOM TIM Division. He is a clinical professor at the University of Texas at Dallas. In 2015 at the Säid Business School at Oxford University, Shawn was named one of the top 50 Outstanding Global Business Educators in the world.

Weilei (Stone) Shi (weilei.shi@baruch.cuny.edu), PhD, University of Pittsburgh, is an associate professor of strategy at Zicklin School of Business, Baruch College - City University of New York. He serves on the editorial board of Journal of Management, Academy of Management Perspectives, and Asia Pacific Fournal 
of Management. His research interests center on the interaction between strategy and international management. Specifically, Stone is interested in examining M\&A and alliances from both temporal and network perspectives. Before joining academia Stone worked for Roland Berger Strategy Consultancy, a global consulting firm headquartered in Munich, Germany.

Manuscript received: August 22, 2016

Final version accepted: September 27, 2016 (number of revisions - 1) Accepted by: Editor-in-Chief Arie Y. Lewin 